\title{
Analysis of Differences in Stock Price and Stock Volume of Trade Before and After Annual Report Award (ARA) Announcement in 2009-2018 in Award Winning Companies Listing in Indonesia Stock Exchange
}

\author{
Nur Widyawati, Ratna Ariesta \\ STIA dan Manajemen Kepelabuhan Barunawati Surabaya \\ nur.widyawati@stiamak.ac.id
}

\begin{abstract}
This study aims to examine whether there are differences in stock prices and trading volume before and after the announcement of the Annual Report Award (ARA) at Award-winning companies. The sample of this research was obtained using purposive sampling method. Based on the existing criteria, 32 companies were obtained as the research sample. Hypothesis testing is done by using paired sample t-tests which were previously tested for normality first on each variable. The results of the study showed that there were no significant differences in share prices and trading volume before and after the announcement of the Annual Report Award (ARA) 20092016. Able to change investor decisions in investing
\end{abstract}

Keywords: Annual Report Award (ARA), Stock Prices, and Stock Trading Volume, Study Even

\section{INTRODUCTION}

The capital market has an important role for a country's economy because the capital market functions as a means for companies to get funds from investors (investors) who place their funds in accordance with the characteristics of the benefits and risks of each instrument.

Investment is basically the placement of a number of funds at this time in the hope of future benefits. One form of investment that is much in demand by investors is investment in the form of shares because it is able to provide an attractive level of profit.

The main requirement that investors want to be willing to invest their funds through the capital market is a feeling of security about their investments. Feelings of security can be realized among others because investors get clear, reasonable, accurate, timely information as a means of decision making.

An important indicator in studying market behavior for investors is to look at price developments and trading market volumes. Stock prices on the exchange are determined by demand and supply. The more demand for shares, the stock price will tend to rise. In contrarily the more offers, the stock price will tend to fall. Ideally, stock prices will increase or decrease in accordance with the prospects of the company's development which is expected to occur. But shares in the capital market basically always fluctuate depending on the economic situation and individual company achievements. Changes in stock prices are a reflection of changes in public valuation of company value.

In line with investors' hard drive to improve the quality of financial information, the Indonesian government and the International Monetary Fund (IMF) introduced the concept of Good Corporate Governance (GCG) as a healthy corporate governance procedure. This concept is expected to protect shareholders from creditors so that they can get their investment back. 
According to Tunggal (2012: 24) Good Corporate Governance (GCG) is a system that regulates, manages, and oversees the process of controlling businesses to raise share value as well as a form of attention to stakeholders.

As one form of accountability for managing the company's resources, the Manager is obliged to prepare an annual report that will be accounted for at the general meeting of shareholders. In its development, as a source of information disclosure, the contents of the annual report are also considered by shareholders. In addition, shareholders and report users not only focus on the company's profitability but also pay attention to corporate social and environmental responsibility, which in turn affects the formation of perceptions of the implementation of Good Corporate Governance (GCG) among corporations in Indonesia.

In order to encourage the application of Good Corporate Governance (GCG) and improve the quality of disclosure in financial information, corporate social and environmental responsibility, several institutions gave several awards, one of which is the Annual Report Award (ARA) held by the Ministry of SOEs, Directorate General of Taxes, The Financial Services Authority (OJK), the Indonesia Stock Exchange, the National Committee on Governance (KNKG) and the Indonesian Institute of Accountants as a tribute to public companies that are considered to have provided the most open information.

The awarding is expected to encourage the application of the principles of Good Corporate Governance (GCG) and be able to improve the quality of financial statements, social responsibility which in turn can increase trust towards investors. The more investors who believe in a company, the more demand for the company's shares. This could affect the increase in stock prices and trading volume of shares in the capital market.

Research on providing annual reports in Indonesia has been carried out by Widyastuti (2010) testing whether there are differences in the Price and Volume of Stock Trading Before and After the Announcement of the Annual Report Award (ARA) in 2008. The study states that there are no differences in stock prices and trading volume before and after the announcement of the 2008 Annual Report Award.

Besides that, Robert (2017) also examined the influence of an Award on corporate social responsibility before examining whether the announcement of the Annual Report Award affects the Average Abnormal Return and Average Trading Volume Activity. The study stated that there were no significant differences between AAR and TVA before and after the announcement of the 2014 Annual Report Award up to 2016. There were differences in the results of research conducted by Widyastuti (2010) and Robert (2017) between the Annual Report Award for the 2007 and 2008 period, making research on the Annual Report Award is more interesting and makes researchers more motivated to conduct the research.

Besides that, Robert (2017) also examined the influence of an Award on corporate social responsibility before examining whether the announcement of the Annual Report Award affects the Average Abnormal Return and Average Trading Volume Activity. The study stated that there were no significant differences between AAR and TVA before and after the announcement of the 2014 Annual Report Award up to 2016. There were differences in the results of research conducted by Widyastuti (2010) and Robert (2017) between the Annual Report Award for the 2007 and 2008 period, making research on the Annual Report Award is more interesting and makes researchers more motivated to conduct the research. 
Based on the previous description, this study aims to examine differences in stock prices and trading volume before and after the announcement of the Annual Report Award (ARA) at award-winning companies listing on the Indonesia Stock Exchange. This research focuses on going public companies that won awards from 2009 to 2016.

\section{THEORETICAL BASIS}

\section{Signaling Theory}

Signaling Theory tells about how a company should give signals to investors. Signals can be in the form of promotions or other information stating that the company is better than other companies. This implies that management in general has more complete and accurate information about the factors that affect a company's value.

Brigham (2011: 184-186) defines signal theory as an action taken by company management that can provide instructions to investors about how management views the company's prospects.

\section{Stock price}

The stock price is the market price of the stock on each closed trading day. The stock price that occurs on the efficient capital market is a reflection of all the information that has been published and occurs on an ongoing balance. For companies that have Go Public, this goal can be achieved by maximizing the market value of the relevant stock prices.

According to Darmadji and Fakhruddin (2011: 14) states that stock prices are formed through the mechanism of demand and supply in the capital market. If a stock experiences excess demand, then the stock price tends to rise. Conversely, if the excess supply then the stock price tends to fall.

\section{Trading Volume Activity (TVA)}

To make investment decisions, Investors will consider the risk and the expected level of profit. Any information circulating will cause a market reaction, the market reaction can be seen from the activity of stock trading volume.

Trading Volume Activity (TVA) is one indicator or sign to determine when to buy / sell shares. In this case, it exemplifies that trading activities and very high volumes in an exchange will be interpreted as a sign that the market will improve.

According to Suryawijaya 2010: 100, the calculation of Trading Volume Activity (TVA) is done by comparing the number of shares of a company traded in a certain period with the total number of shares outstanding in the company during the same time period.

$$
\text { TVA }=\frac{\sum \text { shares traded during the period } t}{\sum \text { Shares Circulated in the period } t}
$$




\section{Event Study}

According Jogiyanto (2013), Event Study is a study that studies the market reaction to an event whose information is published as an announcement. Event Study can be used to test information (Information Content) of an announcement and can also be used to test market efficiency.

One form of testing of the entry of new information, that can affect market reactions through indicators of stock prices and trading volume (TVA). The response of shares in the capital market will be known through changes in stock prices and trading volume of shares. Research using event studies can be conducted to test the efficiency of a capital market for an event related to economic and non-economic activities.

\section{Annual Report Award (ARA)}

Annual Report Award (ARA) is an award given to companies that meet the criteria for completeness in the presentation of annual financial statements, especially for information on company profile, disclosure of the company's vision and mission related to the implementation of Good Corporate Governance (GCG), analysis and management discussion on work company, financial statements in accordance with accounting principles and applicable capital market regulations, and other information relevant to the needs of stakeholders.

This award was held by the Ministry of SOEs (BUMN), the Directorate General of Tax, the Financial Services Authority (OJK), the Indonesia Stock Exchange, the National Committee on Governance (KNKG) and the Indonesian Accountants Association (IAI). This award is expected to make a positive contribution to efforts to restore investor confidence and national economic recovery in general.

\section{Conceptual framework}

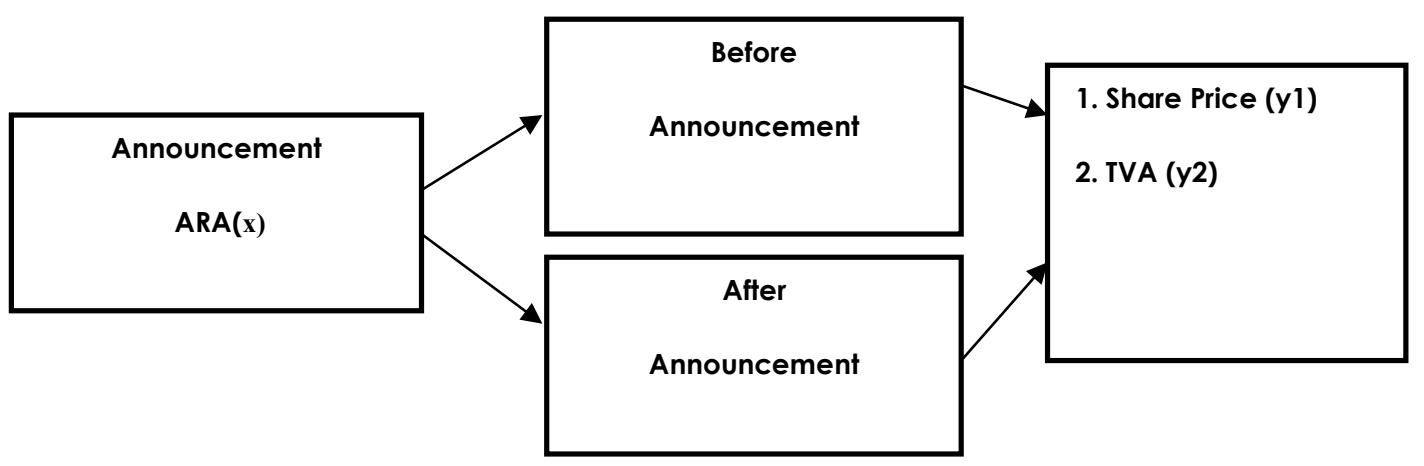

Figure 1. The conceptual framework used

\section{Framework for thinking}

The hypothesis proposed in this study is:

- $\quad \mathrm{H} 1$ : There is a significant difference in the average share price and trading volume of shares before and after the announcement of the Annual Report Award (ARA) for 
the year 2009 - 2016 on Award winning companies listing on the Indonesia Stock Exchange.

- $\quad \mathrm{H} 2$ : There are significant differences in the average share price and trading volume of shares before and after the announcement of the Annual Report Award (ARA) for the year 2009-2016 on Award winning companies listing on the Indonesia Stock Exchange.

\section{RESEARCH METHOD}

\section{Data analysis method}

This research is included in comparative research, while the application of comparative research in this study is used to determine differences in the average value of stock prices and the average trading volume of shares of companies that win the Annual Report Award (ARA) at the time before and after the announcement of the Award.

According to Sugiyono (2015: 54) comparative research is research that compares the state of one or more variables in two or more different samples, or two different times. This research is a research with event study method. In this study the event examined was the Annual Report Award (ARA) event, the aim of which was to look at market reactions in absorbing published information.

In this study, researchers tested the difference in average stock prices and the average volume of stock trading or Trading Volume Activity (TVA) conducted for 10 days, 5 days before and 5 days after the announcement of the Annual Report Award (ARA) in 2009-2016. For more details about the design of this study can be seen in the following picture:

\section{Before Event Date After}

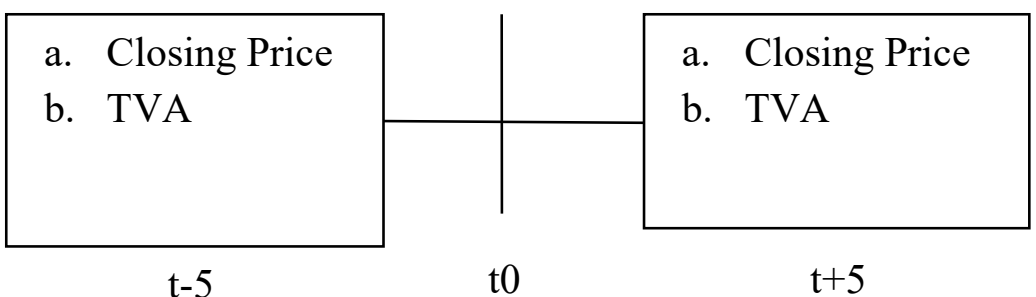

Figure 2. Design of the study

\section{EVENT STUDY}

\section{Population and Sample}

The population in this study was the company that won the Annual Report Award (ARA) in companies listed on the Indonesia Stock Exchange from 2009 to 2016, as many as 97 companies. Sampling using a purposive sampling technique, according to Sugiyono 2015: 218 research with Purposive Sampling technique is a sampling technique where researchers 
determine the sampling with certain considerations by determining special characteristics that are in accordance with the research objectives.

The criteria used in sampling in this study are:

a. The company wins the Annual Report Award (ARA) which is listed on the Indonesia Stock Exchange.

b. The company won the Annual Report Award (ARA) in a row from 2009-2016 using a panel data regression model (pooled data) which is a combination of time series data (inter-time) and cross section data (between individuals / spaces). Based on these criteria, a sample of 32 companies was obtained.

\section{Types, Sources, and Data Collection Techniques}

This research is a type of quantitative research that is a type of research that is more systematic, specific, structured both from the beginning to get a conclusion so that the type of data used is data in the form of numbers or quantitative data.

The data source used in this study came from secondary data obtained through the official website of the Indonesia Stock Exchange, stockok.com and Yahoo Finance. Data collection techniques in this study include library research (Library Research) and internet research (Online Research).

\section{Results and Discussion}

This study examines differences in stock prices and trading volume before and after the announcement of the Annual Report Award (ARA) which is conducted for 10 days, 5 days before the announcement of the award and 5 days after the announcement of the award in 2009 to 2016.

Table 1. Average Daily Share Prices Before and After the Announcement of ARA

\begin{tabular}{|l|l|l|l|}
\hline \multicolumn{2}{|l|}{ Before } & After \\
\hline Period & $\begin{array}{l}\text { Stock } \\
\text { price }\end{array}$ & Period & Stock price \\
\hline$t-5$ & $3.649,97$ & $t+1$ & $3.632,95$ \\
\hline$t-4$ & $3.654,31$ & $t+2$ & $3.654,12$ \\
\hline$t-3$ & $3.685,27$ & $t+3$ & $3.615,26$ \\
\hline$t-2$ & $3.685,12$ & $t+4$ & $3.621,79$ \\
\hline$t-1$ & $3.666,75$ & $t+5$ & $3.633,20$ \\
\hline Mean & $3.668,29$ & Mean & $3.631,46$ \\
\hline
\end{tabular}

Based on table 1 above, it can be seen the average changes in stock prices every day during the period before and after the announcement of the ARA. If seen from the table it can be seen that the average value of the highest share price before the event occurred in period t-3 is Rp. $3,685.27$ while the average value of the lowest share price occurred in the period $t-5$, namely Rp. 3,649.97. 
In the period after the event, the highest average share price occurred in the $t+2$ period, which was Rp. 3,654.12 while the average value of the lowest share price of Rp. 3,615.26 occurred in the $\mathrm{t}+3$ period.

Overall average value of the highest share price during the event period occurred in period t-3 of Rp. 3,685.27 and the lowest average share price occurred in the $t+3$ period of Rp. $3,615.26$.

From the table above it can also be seen that the average share price for the 5 days before the event is Rp. 3,668.29 and the average share price 5 days after the event which is Rp3,631.46. When compared, the average share price before the announcement of the Annual Report Award (ARA) is greater than after the announcement of the Annual Report Award (ARA).

Table 2. Average TVA Before and After ARA Announcement

\begin{tabular}{|l|l|l|l|}
\hline \multicolumn{2}{|l|}{ Before } & \multicolumn{2}{l|}{ After } \\
\hline Period & TVA & Period & TVA \\
& & & \\
\hline$t-5$ & 0,00196873 & $t+1$ & 0,00176284 \\
\hline$t-4$ & 0,00183188 & $t+2$ & 0,00166691 \\
\hline$t-3$ & 0,00201146 & $t+3$ & 0,00168062 \\
\hline$t-2$ & 0,00202701 & $t+4$ & 0,00212159 \\
\hline$t-1$ & 0,00153430 & $t+5$ & 0,00172722 \\
\hline Mean & 0,00187468 & Mean & 0,00179184 \\
\hline
\end{tabular}

Based on table 2 above, it can be seen the average change in TVA every day during the period before and after the announcement of the Annual Report Award (ARA). If seen from the table it can be seen that the highest average TVA value before the event occurred in the $t-2$ period is 0.00202701 while the lowest TVA average value occurs in the $\mathrm{t}-1$ period which is 0.00153430 .

In the period after the event, the highest average TVA value occurred in the $t+4$ period which was 0.00212159 while the lowest average TVA value of 0.00166691 occurred in the $t+2$ period.

Overall, the highest average TVA value during the event period occurred in the $t+4$ period of 0.00212159 and the lowest average TVA value occurred in the t-1 period of 0.00153430 .

From table 2 above it can also be seen that the average TVA for 5 days before the event is 0.00187468 and the average TVA 5 days after the event is 0.00179184 . When compared, the average TVA before the announcement of the Annual Report Award (ARA) is greater than after the announcement of the Annual Report Award (ARA).

\section{Normality test}

In the normality test research used was the Kolmogorov-Smirnov One Sample test with a significance level of 0.05 and using the Statical Program for Social Science (SPSS) software. The purpose of this test is to find out whether the data is normally distributed or not. This is done 
to determine the statistics that will be used in analyzing data. Data is declared normally distributed if the significance is greater than $5 \%$ or 0.05 .

Table 3. Normality Test of Stock Price Data

\begin{tabular}{|l|l|l|}
\hline & Before & After \\
\hline $\mathrm{N}$ & 32 & 32 \\
\hline Kolmogorov-Smirnov & 0,524 & 0,510 \\
\hline $\begin{array}{l}\text { Asymp. Sig } \\
\text { (2-tailed) }\end{array}$ & 0,946 & 0,957 \\
\hline
\end{tabular}

Source: SPSS Output

Based on the SPSS output table this shows that the Asymp.Sig significance value for the share price before the announcement of the Annual Report Award (ARA) is $0.946>0.05$ and the Asymp.Sig for the stock price after the announcement of the Annual Report Award (ARA) is $0.957>0.5$. Then it was concluded that the stock price data is normal distribution data.

Table 4. TVA Data Normality Test

\begin{tabular}{|l|l|l|}
\hline & Before & After \\
\hline $\mathrm{N}$ & 32 & 32 \\
\hline Kolmogorov-Smirnov & 0,626 & 1,160 \\
\hline $\begin{array}{l}\text { Asymp. Sig } \\
\text { (2-tailed) }\end{array}$ & 0,827 & 0,135 \\
\hline
\end{tabular}

Source: Output SPSS

Based on the SPSS output table this shows that the Asymp.Sig significance value for TVA before the announcement of the Annual Report Award (ARA) is $0.827>0.05$ and the Asymp.Sig for TVA after the announcement of the Annual Report Award (ARA) is $0.135>0.05$. Then it can be concluded that the TVA data is normally distributed data.

\section{Hypothesis testing}

Hypothesis testing in this study is determined based on the results of the normality test data; it will be able to determine what test equipment is most suitable for use.

Based on the normality test that has been done, we have obtained data that are normally distributed so that the hypothesis testing in this study is to use the parametric method that is Paired Sample T-Test.

Following are the results of the Paired Sample T-Test test calculation presented in the following table:

Table 5. Paired Sample T-Test Test

\begin{tabular}{|l|l|l|}
\hline & N & Sig \\
\hline $\begin{array}{l}\text { Before and After Stock } \\
\text { Prices }\end{array}$ & 32 & 0,167 \\
\hline TVA Before and After & 32 & 0,656 \\
\hline
\end{tabular}


Based on the table of results of the Paired Sample T-Test above, the Sig. (2-tailed) for the share price is $0.167>0.05$ and the value of Sig. (2-tailed) for TVA is $0.656>0.05$ then H0 is accepted. So it can be concluded that there is no significant difference in the average value of share prices and trading volume of shares before and after the announcement of the Annual Report Award (ARA) in 2009-2016 on award-winning companies listing on the Indonesia Stock Exchange.

\section{DISCUSSION}

Based on the results of hypothesis testing conducted regarding differences in stock prices and trading volume before and after the announcement of the 2009-2016 Annual Report Award, it concluded that there was no significant difference between the average stock price and trading volume before and after the announcement of the 2009 Annual Report Award - 2016 for awardwinning companies listing on the Indonesia Stock Exchange, thus the announcement of the 20092016 Annual Report Award did not receive a response from the market.

Investors consider the ARA announcement to be less relevant information. The market has not given full attention to the ARA event because the companies that won the Annual Report Award (ARA) are big companies, have stable performance, and their shares are the main choice for investors to invest, so investors directly assume that the company that is indeed good corporate governance without considering the announcement of award winners. In addition, investors are also waiting and seeing the situation that occurs in the capital market at that time.

This research has been proven to reject the hypothesis because it is caused by many factors that affect stock prices. These factors include the company's internal conditions, the company's position in a similar industry, Indonesia's macroeconomic conditions, domestic political conditions, market conditions and strength, fluctuations in the exchange rate, and the frequency of transactions.

Even though the Annual Report Award (ARA) information cannot yet be responded to with the average increase in stock prices and the average TVA significantly by investors, it does not mean that information about ARA publications is not useful. The increase in the number of participants in the Annual Report Award from year to year shows that the concern of companies in Indonesia towards the openness and completeness of the presentation of financial statements and the implementation of good corporate governance is starting to grow.

\section{CONCLUSIONS}

Based on the analysis results in the previous chapter the following conclusions can be drawn:

a. There were no significant differences in share prices before and after the 2009-2016 Annual Report Award announcement for award-winning companies listing on the Indonesia Stock Exchange.

b. There was no significant difference in Trading Volume Activity (TVA) before and after the announcement of the 2009-2016 Annual Report Award for award-winning companies listing on the Indonesia Stock Exchange.

\section{Research Limitations}

In a study there must be limitations that make this research still have to be developed. The limitations in this study are as follows: 
a. This study only uses a sample of companies that won the Annual Report Award (ARA) only.

b. This research is still less specific because it does not examine just one type of industry so that it cannot be compared between one company and another.

c. Observations in this study do not pay attention to other events on the date of the announcement of the Annual Report Award (ARA)

\section{Suggestion}

Based on the results of the study and the conclusions that have been drawn, the suggestions that researchers can provide are as follows:

a. For Future Researchers

1) In the next research it is expected to develop more specific research and focus on the announcement of the Annual Report Award in certain fields so that a comparison can be made between certain sectors.

2) The researcher can then increase or decrease the days for the study period. Because the possibility of the market can react faster or slower than the current studied period, which is a period of 10 days, 5 days before and 5 days after the date of the ARA announcement.

3) For further research so that researchers use samples that are not only Annual Report Award events but other events such as the announcement of the Indonesian Sustainability Reporting Award and the Indonesian CSR Award because they can be used as a reference by investors in determining their investments.

b. For Issuers

Issuers should always update information about company developments on their website well and regularly, because in accordance with current trends, investors are no longer based solely on financial statements in making decisions but also on other information held by companies that can make investors the more sure of the investment.

c. For Award Organizers

The organizer of the Annual Report Award should conduct more intensive socialization, both regarding the implementation of the award itself and the importance of the Annual Report Award program, especially for companies and investors to be publicly known so that it will have a positive impact on the award event

\section{REFERENCES}

Anoraga, P. 2013. Pengantar Pasar Modal. Jakarta: Rineka Cipta.

Arikunto, S. 2010. Prosedur Penelitian Suatu Pendekatan Praktek. Jakarta: Rineka Cipta.

Brigham, F. E. \& Juel F. H. 2011. Dasar-Dasar Manajemen Keuangan. Buku 2. Edisi Kesepuluh. Jakarta: Salemba Empat.

Budiman, S. 2009. Pengaruh Pengumuman ISRA terhadap Abnormal Return dan Volume Perdagangan Saham. Jurnal Ilmiah Vol no.3

Darmadji, Tjiptono. \& Fakhruddi. 2011. Pasar Modal Indnesia. Jakarta: Salemba Empat.

Ekawati, Rika Kharlina. 2011. Analisis Perbedaan Harga Saham Sebelum dan Sesudah Pengumuman ARA Di Bursa Efek Indonesia. Jurnal IImiah Vol no.1 
Fahmi, J dan Nor Hadi. 2013. Teori Portofolio Dan Analisis Investasi. Edisi Kelima. Yogyakarta: Alfabeta Husnan, F. 2015. Dasar-Dasar Teori Portofolio Dan Analisis Sekuritas. Edisi Empat. Yogyakarta: UUP STIM YKPN.

Jogiyanto, H. 2013. Teori Portofolio Dan Analisis Investasi. Yogyakarta: UPP YPKPN.

McCaston, M. Katherine. 2010. Tips For Collecting, Reviewing, and Analyzing Secondary Data. (www.pqdl.care.org), diakses 20 Juni 2019.

Rusydayaba, Z. 2009. Pengaruh Pengumuman Annual Report Award Terhadap Average Abnormal Return Dan Average Trading Volume Activity (Study Empiris Pada Perusahaan Penerima Penghargaan Annual Report Award Periode 2007-2008).

Sjahrial, D. 2017. Manajemen Keuangan Lanjut. Jakarta: Mitra Wacana Media.

Siswandari, S. 2009. Aplikasi SPSS Pada Statistik Non Parametrik. Jakarta: PT Alex Media Komputindo.

Sugiyono, 2015. Statistik Untuk Penelitian. Bandung: Alfabeta.

Surayawijaya, M.A. 2010. Reaksi Pasar Modal Indonesia Terhadap Peristiwa Politik Dalam Negeri (Event Study Pada Peristiwa 27 Mei 1996). Kelolah, VII (18): 145.

Tunggal, Amin Widjaja. 2012. Analisis Teknikal Di Bursa Efek. Yogyakarta: Harvarindo

Widyastuti, F. 2010. Analisis Perbedaan Harga Saham Dan Volume Perdagangan Saham Sebelum Dan Sesudah Pengumuman Indonesian CSR Award 2008 Pada Perusahaanpemenang Indonesia CSR Award Yang Listing Di BEl.

https://www.indonesia-investments.com

https://penelitiandeskriptifkomparatifkausal.com

https://sahamok.com

https://yahoofinance.com

https://idx.co.id

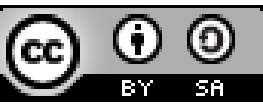

(C) 2020 by the authors. Submitted for possible open access publication under the terms and conditions of the Creative Commons Attribution (CC BY SA) license (https://creativecommons.org/licenses/by-sa/3.0/). 